\title{
SOCJALIZACJA POLITYCZNA W PRZEBIEGU ŻYCIA - PERSPEKTYWA KONTYNUACJI I ZMIANY
}

\begin{abstract}
AвSTRACT. Hildebrandt-Wypych Dobrochna, Socjalizacja polityczna w przebiegu życia - perspektywa kontynuacji i zmiany [A Life-Course Model of Political Socialization - a Perspective of Continuity and Change]. Studia Edukacyjne nr 49, 2018, Poznań 2018, pp. 373-400. Adam Mickiewicz University Press. ISSN 1233-6688. DOI: 10.14746/se.2018.49.22
\end{abstract}

The following text presents various alternative theoretical approaches in political socialization research. Some of the theoretical insights provided by the functional, systemic and interpretative perspectives are identified in order to depict the discussion around the continuity and change within the political socialization research. Whereas in the first period of political socialization research the aim was to explain the continuity in the development of political orientations, it was later forced to account for modification and the potential for change (especially when addressing the interpretative issues of identity politics). After describing the field's theoretical shifts, the life-course model of political socialization is presented. The life-course model attempts to deal with the problem of continuity and change in the political socialization process, pointing to its remarkable complexity and lifelong flexibility. It offers a systematic, interdisciplinary and holistic way of conceptualizing political socialization. It points to the importance of political socialization research in demonstrating interdependence between objective functions of the political system and subjective political learning of a reflexive individual.

Key words: political socialization, life-course, political studies, citizen, citizenship, political change

\section{Wprowadzenie}

Systemy polityczne dążą do odtworzenia swoich kultur i struktur, a jednym z mechanizmów służących stabilności, ciągłości kulturowej i trwałości elementów systemu politycznego jest socjalizacja polityczna. Jednocześnie, nieuniknionym jej wymiarem jest zmiana, pozwalająca różnym elementom systemu politycznego adaptować się do ewoluujących warunków społeczno-kulturowych. Celem niniejszego tekstu jest zdefiniowanie socjalizacji politycznej w świetle zmieniających się podejść teoretycznych, w różnym stopniu 
akcentujących napięcie między kontynuacją a zmianą. Najwcześniej pojawiła się - skupiona na zabezpieczeniu ciągłości i równowagi systemu politycznego - perspektywa funkcjonalna. Następnie do głosu doszło - starające się uwzględnić mechanizmy zmiany - podejście systemowe. Jeszcze później wyłoniło się podejście interpretacyjne, podkreślające znaczenie społecznego konstruowania i negocjowania ram socjalizacyjnych w procesie autonomicznego, aktywnego i podmiotowego rozwijania tożsamości. Przedstawiony w ostatniej części tekstu model socjalizacji politycznej w przebiegu życia (a life-course model of political socialization) redefiniuje podejście do człowieka jako podmiotu socjalizacji politycznej, akcentując znaczenie plastyczności, otwartości i całożyciowej perspektywy rozwoju orientacji politycznych. Integracja różnych ujęć teoretycznych i ustaleń empirycznych w ramach tego modelu uwypukla interdyscyplinarność badań nad socjalizacją polityczną, przeważająca "nad rygoryzmem definicyjnym z punktu widzenia jednej tylko dyscypliny naukowej" ${ }^{\prime 1}$. Uwzględnienie punktu widzenia pedagogiki, politologii, socjologii, psychologii społecznej oraz filozofii politycznej daje szansę na pełniejszą analizę socjalizacji politycznej jako jednego z wymiarów ogólnego procesu socjalizacji. Stanowi próbę przekroczenia eklektyzmu teorii i metod badawczych, charakteryzującego wcześniejsze studia nad socjalizacją polityczną. Adekwatnie w tym kontekście brzmi fragment wprowadzenia do książki Socjalizacja polityczna, autorstwa Edwarda Greenberga:

Będziemy definiować socjalizację polityczną w dość swobodny sposób jako proces, w wyniku którego jednostka nabywa postawy, przekonania i wartości, odnoszące się do systemu politycznego, którego jest członkiem oraz do swojej własnej roli jako obywatela tego systemu. Taka definicja obejmuje wiele podejść teoretycznych, nie skupiając się na którymkolwiek z nich w szczególności”².

\section{Funkcjonalistyczne spojrzenie na socjalizację polityczną}

Termin „socjalizacja polityczna” po raz pierwszy pojawił się w druku w podręczniku psychologii społecznej z 1954 roku i choć użyto go w wąskim kontekście zachowań wyborczych, znalazła się tam wyraźna wskazówka, że badanie procesów rozwojowych, prowadzących do nabycia przez jednostki tożsamości politycznych, przekonań, wartości, postaw i wzorów zachowań, mogłoby znaleźć zastosowanie $w$ innych obszarach życia politycznego. Już w roku 1959 ukazało się pierwsze opracowanie naukowe, w całości poświęcone problematyce socjalizacji politycznej - Political Socialization, autorstwa

\footnotetext{
${ }_{1}^{1}$ T. Sasińska-Klas, Socjalizacja polityczna. Teorie, badania, ustalenia, Kraków 1992, s. 23.

2 E.S. Greenberg, Consensus and Dissent: Trends in Political Socialization Research, [w:] Political Socialization, red. E.S. Greenberg, London - New York 2017, s. 3.
} 
Herberta H. Hymana. Jego analiza koncentrowała się na trzech wymiarach życia politycznego: uczestnictwie $\mathrm{w}$ polityce, wyborze radykalnych albo konserwatywnych celów politycznych oraz wsparciu dla demokratycznych bądź autorytarnych form rządzenia ${ }^{3}$. Badania nad socjalizacją polityczną zyskały ogromną popularność w latach 60. i 70. XX wieku, między innymi jako nurt badań nad wzrostem aktywizmu uczniowskiego i studenckiego tamtego okresu. W ramach ówczesnych badań dokonano między innymi konceptualizacji sposobów rozwoju wiedzy i postaw politycznych młodzieży w ramach odgórnych procesów uczenia się. Socjalizacja polityczna została uznana za subdyscyplinę nauk politycznych ${ }^{4}$, choć badania postaw politycznych młodzieży prowadzone były zarówno przez politologów ${ }^{5}$, jak i w ramach współpracy politologów z psychologami ${ }^{6}$, a także przez zespoły badawcze złożone wyłącznie w psychologów ${ }^{7}$.

We wczesnych badaniach socjologicznych nad socjalizacją polityczną przyjęto perspektywę funkcjonalną ${ }^{8}$, którą z powodzeniem może rekapitulować definicja Kennetha Langtona z 1969 roku, określająca socjalizację polityczną jako „sposób, w jaki społeczeństwo dokonuje transmisji swojej kultury politycznej z pokolenia na pokolenie" ${ }^{\prime 9}$. Sięgając między innymi do teorii systemu społecznego Talcotta Parsonsa, ukazywano proces socjalizacji politycznej jako siłę stabilizującą system polityczny, działającą w ramach oficjalnych instytucji i struktur systemu. Rozwijane początkowo koncepcje socjalizacji politycznej osadzone były w - zapoczątkowanym przez T. Parsonsa - socjologicznym nurcie badań systemów politycznych. Zdaniem prekursorów studiów and socjalizacją polityczną, Gabriela Almonda i Binghama Powella, socjalizacja polityczna to kluczowy proces utrzymania „politycznej stabilności i rozwoju"10. Jedna z wcześniejszych i ważniejszych definicji socjalizacji politycznej mówi o niej, jako o „procesie, w ramach którego kultury politycz-

3 P.C. Wasburn, T.J. Adkins Covert, Making Citizens. Political Socialization Research and Beyond, Cham 2017, s. 3.

${ }^{4}$ R.E. Dawson, K. Prewitt, Political Socialization, Boston 1969; K.P. Langton, Political Socialization, New York 1969; D. Jaros, Socialization in Politics, New York 1973.

${ }^{5}$ F.I. Greenstein, Children and politics, New Haven 1965; K. Jennings, R. Niemi, Continuity and change in political orientations: A longitudinal study of two generations, The American Political Science Review, 1975, 69.

${ }^{6}$ R.D. Hess, J. Torney, The Development of Political Attitudes in Children, Chicago 1967; D. Easton, J. Dennis, Children in the political system: Origins of political legitimacy, New York 1969.

7 J. Adelson, L. Beall, Adolescent perspectives on law and government, Law and Society Review, 1969, 495.

8 Por. G. Bokszańska, Znaczenie kultury politycznej dla funkcjonowania systemu politycznego, Edukacja Polityczna, 1986, 8.

${ }_{9}$ K.P. Langton, Political Socialization, s. 4.

${ }^{10}$ G.A. Almond, G.B. Powell, Comparative Politics. A Developmental Approach, Boston 1966, s. 65 . 
ne są podtrzymywane albo zmieniane"11, a zmiany w kulturze politycznej wpływają na zmiany w całym systemie politycznym. Polityka jest $\mathrm{z}$ tej perspektywy jednym $z$ istotniejszych elementów stabilizujących system społeczny; jest - przywołując pogląd G. Almonda - obszarem socjalizacji jednostki, ćwiczenia ról społecznych, a także utrzymywania konkurujących ze sobą interesów społecznych w stanie equilibrium. Równowagę systemu politycznego osiąga się w ramach tych interakcji, które dotyczą użycia bądź groźby użycia prawomocnego przymusu fizycznego ${ }^{12}$. Prawomocne użycie przemocy, zwane przez Davida Eastona „prawomocnym rozdziałem wartości”, jest integralnym elementem większości ówczesnych definicji systemu politycznego. Prawomocna władza może - w imię stabilności systemu - karać, egzekwować i przymuszać. Jak podkreślają w tym kontekście G. Almond i G.B. Powell:

Zgadzamy się z Maxem Weberem, że legitymizowana siła jest nicią, która przeplata się przez działania systemu politycznego, nadając mu specjalne znaczenie i zwartość. Władza polityczna i tylko ona, ma ogólnie akceptowane na danym terytorium prawo stosowania przymusu i wymagania posłuchu na jego podstawie ${ }^{13}$.

W początkowym okresie rozwoju badań nad socjalizacją polityczną zdecydowana większość teoretyków za jej główny cel uznawała zabezpieczenie trwałości ładu społecznego i ciągłości systemu politycznego we względnie niezmienionej formie. David Easton (krytycznie oceniający funkcjonalne spojrzenie na socjalizację polityczną) wskazywał na możliwość rozpatrywania stabilności systemu politycznego w dwóch znaczeniach. W szerszym ujęciu, owo equilibrium odnosiło się do możliwości sprawnego rozwiązywania konfliktów interesów („problemów”), prowadzonego w imię - opartego na powszechnej zgodzie społecznej - poczucia sprawiedliwości. Niestabilność systemu politycznego utożsamiana była z nieprzewidywalnością, brakiem konsensusu i stosowaniem wobec obywateli (uznawanego za niesprawiedliwy) przymusu. W wąskim rozumieniu, pojęcie stabilności systemu politycznego odnosiło się do trwałości działań państwa w dłuższej perspektywie czasowej. Gwarantem owej trwałości było pokoleniowe reprodukowanie się wartości, postaw i przewidywalnych zachowań względem tegoż systemu. Jeden z pierwszych teoretyków socjalizacji politycznej H. Hyman wyjaśniał celowość procesu adaptacji młodzieży do wzorów postaw i zachowań politycznych dorosłych następująco:

${ }^{11}$ Tamże, s. 64 .

${ }_{12}$ T. Sasińska-Klas, Socjalizacja polityczna, s. 27; G.A. Almond, G.B. Powell, Comparative Politics, s. 17-18.

${ }^{13}$ G. Almond, G.B. Powell, System polityczny, jego otoczenie, wejścia i wyjścia, [w:] Władza i polityka. Wybór tesktów ze wspótczesnej politologii zachodniej, red. M. Ankwicz, Warszawa 1988, s. $24-25$. 
Znaczenie takiego ujęcie polityki jako wyuczonych zachowań polega na zrozumieniu stabilności systemu i to jest oczywiste - jednostki ludzkie muszą uczyć się wcześnie zachowań politycznych i tego, jak je utrwalać. Jeśli nie będzie się tego czynić regularnie - powstanie chaos $^{14}$.

Wszystkie konceptualizacje socjalizacji politycznej w ramach paradygmatu strukturalno-funkcjonalnego akcentują znaczenie międzypokoleniowej transmisji wiedzy i umiejętności, służących utrzymaniu ładu społecznego i osiągnięciu konsensusu politycznego. Takie stanowisko odnajdujemy między innymi u Roberta Sigela, definiującego socjalizację polityczną jako „proces uczenia się, poprzez który normy polityczne i zachowania akceptowane przez system polityczny są przenoszone z generacji na generację"15. Również Harry Eckstein zwraca uwage, iż celem socjalizacji politycznej jest przygotowanie jednostek do pełnienia ról społeczno-politycznych. Dzieje się tak w efekcie nabywania przez jednostkę wartości, postaw, sądów poznawczych i uczuć wobec systemu politycznego, dzięki którym jest ona zdolna do działania w obszarze polityki. Z perspektywy ogólnospołecznej, socjalizacja polityczna umożliwia dojście do konsensusu politycznego ${ }^{16}$.

Funkcjonalistyczne spojrzenie na socjalizację polityczną jako na proces uczenia się akceptowanych przez system społeczno-polityczny postaw i zachowań prezentowali również Gabriel A. Almond i Sidney Verba - twórcy jednej z najbardziej znaczących koncepcji socjalizacji politycznej. Ich badania porównawcze, lokujące się w obszarze socjologii polityki, dotyczyły pięciu społeczeństw demokratycznych (USA, Wielkiej Brytanii, Włoch, Francji i RFN). Analizowali oni wpływ socjalizacji politycznej na formowanie kultury politycznej, definiowanie obywatelstwa oraz uczestnictwa obywatelskiego, włączając w ów proces również doświadczenia spoza sfery bezpośrednio politycznej, związane na przykład z wychowaniem w rodzinie i szkole ${ }^{17}$. W jednej z wcześniejszych definicji G. Almonda „końcowy produkt” socjalizacji politycznej określa się jako „zbiór postaw - wiedzy, wzorów wartości, uczuć - wobec systemu politycznego, jego różnorakich ról oraz podmiotów, spełniających role w polityce" ${ }^{\prime 18}$. W procesie socjalizacji politycznej, ujmowanym u G. Almonda jako wprowadzanie w kulturę polityczną, zależność

${ }^{14}$ T. Sasińska-Klas, Socjalizacja polityczna, s. 43; H.H. Hyman, Political Socialization. A Study in the Psychology of Political Behavior, New York 1959, s. 17.

${ }_{15}$ T. Sasińska-Klas, Socjalizacja polityczna, s. 43.

${ }^{16}$ E.M. Marciniak, Socjalizacja polityczna - wprowadzenie teoretyczne, [w:] Socjalizacja polityczna młodego pokolenia Polaków, red. W. Jakubowski, E.M. Marciniak, P. Załęski, Warszawa 2008, s. 16.

${ }^{17}$ Co powoduje tendencje ku niestabilności kultury politycznej, a co wspomaga jej harmonijne i stabilne trwanie? T. Sasińska-Klas, Socjalizacja polityczna, s. 44.

${ }_{18}$ G.A. Almond, Introduction: A Functional Approach to Comparative Politics, [w:] The Politics of the Developing Areas, red. G.A. Almond, J.S. Coleman, Princeton 1960, s. 27-28. 
między socjalizacją polityczną a kulturą polityczną jest zależnością zwrotną. Jan Garlicki precyzuje ową zależność następująco: „dominująca w danym społeczeństwie kultura polityczna wyznacza ramy i treści prowadzonej socjalizacji, przynajmniej w ramach oficjalnych instytucji i struktur systemu"19. Jednocześnie, jak podkreśla sam G. Almond, kultury politycznej nigdy nie należy traktować jako jednokierunkowej "przyczyny” struktur i zachowań politycznych. Trwałość kultur politycznych wyjaśnia odwołanie do doświadczeń historycznych, ograniczeń strukturalnych oraz istnienia "pierwotnego zespołu postaw", który ma tendencję do trwania, mimo pojawiających się presji na przekształcenie. Stabilność kultury politycznej wyjaśniał G. Almond odwołując się do podstawowego założenia teorii kultury politycznej:

Głosi ono, że jakkolwiek potężne będą wysiłki i represyjna struktura, jakkolwiek monopolistyczne i przekonywujące środki przekazu i kuszący system bodźców, kultura polityczna stawiać będzie poważne ograniczenia zmianom struktur i zachowań, ze względu na to, że kluczowe postawy będą miały tendencję do przetrwania w znacznym stopniu i przez znaczny okres czasu ${ }^{20}$.

Paradygmat funkcjonalny za pierwszoplanowy cel socjalizacji uznawał przyczynianie się do osiągnięcia bądź utrzymania równowagi systemu politycznego. Jak słusznie zauważa Teresa Sasińska-Klas: „Nie pomijano zupełnie zmian, ale traktowano je jako drugorzędne, a nie główne skutki socjalizacji”21. Socjalizacja polityczna uznawana była w pierwszym rzędzie za proces transmisji kulturowej („,wprowadzania w kulturę"), w ramach którego młodzież internalizuje pożądane w swoim środowisku życia orientacje polityczne. Pojawia się w tym kontekście wątpliwość, że orientacje te, choć względnie stałe, nie mogą być niezmienne. Nawet funkcjonalizm uznawał socjalizację polityczną za proces całożyciowy, zawierający w sobie potencjał zmiany. W procesie socjalizacji politycznej dochodzi do krystalizacji orientacji politycznych opartych na istniejących już wzorach, jednakże postawy wobec polityki mogą ulegać zmianom, zależnie od osobistych doświadczeń, a także ważnych (granicznych) wydarzeń politycznych, wywierających niekiedy wpływ na duże części społeczeństwa, a nawet całe pokolenia. Przedstawiciele szkoły funkcjonalnej w socjologii, na przykład G. Almond i S. Verba, rozbieżności między oddziaływaniem (charakterem socjalizacji) a efektem (stabilną kulturą polityczną) interpretowali jako - powodujący niestabilność systemu politycznego - „brak jednorodności w doświadczeniu subiektywnym”. Krytycy funkcjona-

${ }^{19}$ J. Garlicki, A. Noga-Bogumilski, Kultura polityczna w społeczeństwie demokratycznym, Warszawa 2004, s. 24.

${ }^{20}$ G. Almond, Komunizm a teoria kultury politycznej, [w:] Wtadza i polityka. Wybór tesktów, s. 33 .

${ }^{21}$ T. Sasińska-Klas, Socjalizacja polityczna, s. 41. 
lizmu, między innymi David Easton, wskazywali na zauważalne ograniczenia tezy o stabilności jako celu procesu socjalizacji, podkreślając: „Nie można pomijać rezultatów socjalizacji (...), które prowadzą do politycznej różnorodności, konfliktu czy wręcz zmiany"22. Edward Greenberg, w eseju z 1970 roku otwierającym publikację Political socialization, zatytułowanym „Konsensus i sprzeciw: tendencje w badaniach socjalizacji politycznej", również wskazywał na wątpliwości pojawiające się już na przełomie lat 60. i 70. XX wieku, co do przekonania o homogeniczności procesu socjalizacji politycznej. Zwracał on uwagę na konieczność podjęcia wysiłku reinterpretacyjnego i zakwestionowania jednostronności wcześniejszych badań, opierających analizy procesu socjalizacji politycznej na założeniu o stabilności, pluralizmie i trwale demokratycznym charakterze takich systemów politycznych jak amerykański ${ }^{23}$.

\section{Socjalizacja polityczna w podejściu systemowym Davida Eastona}

Teoretyczna interpretacja procesu socjalizacji Davida Eastona, jednego z pierwszych badaczy analizujących politykę w kategoriach systemowych, zakładała, iż dla zrozumienia trwałości systemu politycznego konieczne jest uwzględnienie zarówno mechanizmów stabilności systemu, jak i mechanizmów zmiany. D. Easton w odmienny od funkcjonalistów sposób ujmował poznanie celów procesu socjalizacji. Obok konieczności poznania czynników, gwarantujących funkcjonalność socjalizacji politycznej względem potrzeb systemu politycznego (kształtowania ładu politycznego państwa), zwracał uwagę na konieczność poznania czynników zmiany. Stawiał w swojej teoretycznej propozycji pytanie nie, jak system polityczny „utrzymuje się w konkretnych okolicznościach, ale jak systemy polityczne trwają zarówno w stabilnym środowisku, jak i w zmieniającym się świecie" ${ }^{24}$. Zmiana wielkości bądź jakości któregokolwiek ze składników systemu (pojawienie się nowej partii politycznej, nowego ruchu społecznego, nowego środka masowego przekazu, wzrost wpływów instytucji międzynarodowych na działania instytucji krajowych) wywołuje napięcia, w wyniku których inne składniki systemu mogą ulec przekształceniom. O ile ów zmieniony składnik systemu politycznego nie zostanie przywołany do porządku w wyniku działania mechanizmów regulacyjnych, system zmienia dotychczasowe zasady działania. Mechanizmy stabilizowania systemu politycznego współwystępują obok me-

\footnotetext{
22 Tamże, s. 44.

23 E.S. Greenberg, Consensus and Dissent, s. 3.

24 J.C. Johari, Comparative Politics, New Delhi 1982, s. 53.
} 
chanizmów jego destabilizacji i to w sytuacji zarówno harmonii i ładu, jak też braku porządku społecznego 25 .

Główne założenia modelu badań systemów politycznych ${ }^{26} \mathrm{D}$. Eastona odnoszą się do dwóch rodzajów interakcji między systemem a jego otoczeniem: wejść (z otoczenia) i wyjść (do otoczenia). Dwa typy wejść do systemu politycznego to żądania i poparcie. Pierwsze dotyczą zgłaszanych do systemu politycznego postulatów, dotyczących na przykład większej sprawiedliwości, zmniejszenia przemocy, możliwości uczestnictwa politycznego dla grup defaworyzowanych, a także adaptacji i pozytywnej odpowiedzi na nowo pojawiające się wartości. Co ważne, żądania nie są formułowane wyłącznie przez społeczeństwo, którego system jest częścią. Pochodzą zasadniczo z trzech źródeł: społeczeństwa (jego poszczególnych grup), elit politycznych (prezydentów, ministrów, sędziów, parlamentarzystów), ale także z otoczenia międzynarodowego (inwazje, kontrola, groźba bądź pomoc z innych systemów politycznych) ${ }^{27}$. Drugim typem wejść są poparcia, przyjmujące postać zarówno aktywną, związaną z wytwarzaniem zasobów politycznych (głosowanie, udział w kampaniach, zaangażowanie w podejmowanie decyzji, walka na rzecz określonego programu politycznego), jak i pasywną, określaną jako poparcia bierne (płacenie podatków, nieuchylanie się od służby wojskowej, prace publiczne, przestrzeganie prawa, szacunek dla symboli, ceremonii i rytuałów państwowych). D. Easton opisuje znaczenie obu rodzajów wejść do systemu następująco:

Wejścia w postaci żądań nie wystarczają do utrzymania systemu w działaniu. Są one tylko surowcem, z którego produkuje się końcowe produkty, nazywane decyzjami. Aby utrzymać system $\mathrm{w}$ ruchu niezbędne jest dostarczenie mu energii w postaci działań czy postaw popierających czy stawiających opór systemowi politycznemu, żądaniom, które w nim występują i decyzjom, które są w nim podejmowane ${ }^{28}$.

Żądanie i poparcia, kierowane do systemu politycznego z jego otoczenia (wejścia systemu), przekształcane są w decyzje i działania (wyjścia systemu), podejmowane przez osoby sprawujące władzę. Dynamika systemu politycznego ujawnia się najpełniej na poziomie wyjść, kiedy „zwiększenie nasilenia określonego typu postulatów zagraża równowadze systemu

${ }^{25}$ T. Sasińska-Klas, Socjalizacja polityczna, s. 45.

${ }^{26}$ D. Easton definiował system polityczny jako „zestaw interakcji wyodrębniony z całości zachowań społecznych, poprzez które dochodzi do alokacji wartości w społeczeństwie", gdzie "autorytatywna alokacja wartości” rozumiana jest jako rozdział dóbr, przypisanie wartości dobrom, a także rozsądzanie sporów co do wartościowych dóbr, dokonywane przez grupy sprawujące władzę (por. J.C. Johari, Comparative Politics, s. 55).

${ }^{27}$ G. Almond, G.B. Powell, System polityczny, jego otoczenie, s. 28.

28 Tamże. 
i dlatego wywołuje reakcje neutralizujące lub oddalające postulat" ${ }^{29}$. System w różnym stopniu reaguje na wejścia, a zakres owej reakcji (w postaci działań i decyzji) świadczy o otwartości systemu politycznego. Otwartość systemu politycznego oznacza zatem zarówno wymianę informacji z otoczeniem, jak też jakość i ilość informacji wysyłanych do innych systemów (np. edukacyjnego). „Wbudowane” w system mechanizmy samoregulujące pozwalają na wewnętrzne przystosowywanie się systemu: formułowanie odpowiedzi na poparcia oraz przyjmowanie bądź odrzucanie żądań. G. Almond i G.B. Powell dzielą wyjścia na następujące kategorie: ekstrakcje (np. podatki bądź świadczone usługi), dystrybucja (np. dóbr, usług, możliwości, stanowisk), wyjścia symboliczne (np. potwierdzanie symboli politycznych, potwierdzanie wartości bądź prezentacja oświadczeń politycznych) oraz regulacje zachowań ${ }^{30}$. Wśród wielu form regulacji zachowań szczególne znaczenie ma socjalizacja, traktowana w podejściu systemowym D. Eastona jako ważny mechanizm „poprzez który można zmierzać do zmniejszenia presji wobec systemu i stymulowania zachowań opartych na autorytatywnie upowszechnianych w społeczeństwie wartościach" ${ }^{31}$. System polityczny nie mógłby istnieć bez minimalnego poparcia oraz konsensusu co do podstawowych treści politycznych, które generowane są $\mathrm{w}$ procesie socjalizacji politycznej.

Istotnym aspektem analizy systemowej jest pojęcie granicy i otoczenia danego systemu politycznego. Zarówno w przypadku systemów społecznych, jak i - traktowanych jako ich podsystemy - systemów politycznych, problem granic zawsze stanowił teoretyczne i empiryczne wyzwanie. Większość badaczy jest zgodna, że granice systemów politycznych są dynamiczne i w zmiennym (większym lub mniejszym) zakresie przenikają inne układy społeczne (np. w czasie wojny, przy zmianie interakcji z otoczeniem międzynarodowym, np. rozwoju handlu, wymiany kulturalnej czy komunikacji). W. Szczepański przyjął bardzo szerokie ujęcie, w myśl którego "granice systemów międzynarodowych pokrywają się z reguły z granicami geograficznymi państw bądź ich zbiorowości, będących elementami tych systemów, choć nierzadko je przenikają" ${ }^{\prime 32}$. Wytyczenie granic pozwala na odróżnienie elementów systemu politycznego od elementów jego otoczenia, rozumianego jako zestaw składników, nie będących - w wąskim rozumie-

${ }^{29}$ K. Ostrowski, Rola związków zawodowych w polskim systemie politycznym, Warszawa 1970, s. 124.

${ }^{30}$ G. Almond, G.B. Powell, System polityczny, jego otoczenie, s. 29.

${ }^{31}$ T. Sasińska-Klas, Socjalizacja polityczna, s. 49.

${ }_{32}$ W. Szczepański, Europa w myśli politycznej de Gaulle'a. Próba analizy systemowej, Warszawa 1979, s. 45. 
niu - politycznymi, ale mogących wywołać zmianę systemu politycznego. Aby formułować i realizować cele kolektywne, społeczeństwa „używają” systemów politycznych, w ramach których inicjowane są interakcje z otoczeniem wewnętrznym oraz zewnętrznym (międzynarodowym). $Z$ jednej strony, systemy polityczne podejmują działania zmierzające do uzyskiwania zasobów ze środowiska, rozdzielania korzyści między różne grupy społeczne, regulowania zachowań obywateli i zapewniania bezpieczeństwa. $\mathrm{Z}$ drugiej strony,

systemy polityczne same są w znacznym stopniu kształtowane przez otoczenia, w których działają. Problemy, które stają przed obywatelami i przywódcami społeczeństwa, dostępne zasoby dla ich rozwiązania, umiejętności i wartości kształtujące zbiorowe wierzenia i zachowania - wszystko to jest pod wpływem wewnętrznego i zewnętrznego otoczenia ${ }^{33}$.

Model wejść i wyjść D. Eastona pozwala na uwzględnienie dynamicznego charakteru systemu politycznego, skupiając się jednak na procesach adaptacji systemowej i celowym przekierowywaniu działań systemu politycznego w wyniku płynących z wewnątrz (polityka krajowa) i z zewnątrz (polityka międzynarodowa) informacji zwrotnych. Analiza systemowa daje możliwość badania procesów rozwoju politycznego oraz relacji między systemem a otoczeniem. Dzięki sprzężeniu zwrotnemu system polityczny aktywnie reaguje na przemiany w swoim otoczeniu: dąży do równowagi, ale i sam podlega zmianie. $W$ analizie systemowej zależności między dynamiką systemu politycznego a potrzebą jego stabilizacji określane są mianem trwałości bądź równowagi systemu. System polityczny dąży do homeostazy, ale jego składniki i otoczenie są dynamiczne. System polityczny utrzymuje swój stan w ewoluującym otoczeniu za pomocą mechanizmów wewnętrznego przystosowywania się. Ważki mechanizm tego typu stanowi tu proces socjalizacji politycznej, który „można także traktować jako sposób reagowania na system” 34 i generowania minimalnego poziomu poparcia dla treści politycznych, bez których system nie mógłby trwać. Proces socjalizacji politycznej jest w swej istocie koncepcją konserwatywną, ponieważ jego zasadniczym celem jest przetrwanie systemu politycznego. Zarówno w społeczeństwach totalitarnych, jak i w otwartych społeczeństwach demokratycznych efektem procesu socjalizacji jest utrzymanie wzorów politycznego działania poprzez ukierunkowanie obywateli na wsparcie, jeśli nie istniejącego status quo, to przynajmniej zasadniczych aspektów istniejącego reżimu politycznego ${ }^{35}$.

${ }^{33}$ G. Almond, G.B. Powell, System polityczny, jego otoczenie, s. 26.

${ }^{34}$ T. Sasińska-Klas, Socjalizacja polityczna, s. 49.

35 J.C. Johari, Comparative Politics, s. 216. 


\section{Interpretacjonistyczne podejście do socjalizacji politycznej}

Obszar badań nad socjalizacją polityczną dzieci i młodzieży doświadczał w kolejnych latach następujących po sobie okresów stagnacji i rozwoju. $\mathrm{W}$ porównaniu z niezwykłą popularnością subdyscypliny $\mathrm{w}$ latach 70 . XX wieku, zainteresowanie tym nurtem badań zmalało ${ }^{36}$. Mimo to, rozwijane od lat 60. XX wieku, w ramach studiów nad socjalizacją polityczną koncepcje badawcze przeniknęły do nauk politycznych, znajdując zastosowanie w wielu subdyscyplinach, między innymi badaniach opinii publicznej, zachowań wyborczych, kultury politycznej oraz ruchów politycznych ${ }^{37}$.

Wraz z rozwojem w późnych latach 90 . XX wieku tak przełomowych teorii psychologicznych, jak teoria społecznego uczenia się Alberta Bandury czy konstruktywizm poznawczy Jeana Piageta, zaczęto coraz odważniej akcentować znaczenie autonomicznego i celowego działania podmiotów $\mathrm{w}$ procesie socjalizacji politycznej. Uczenie się bycia obywatelem zaczęto rozumieć jako indywidualny proces konstruowania subiektywnej wiedzy w kontekście społecznym, czyli w sytuacji otwarcia się na interakcje międzyludzkie i poglądy innych, przy jednoczesnej łączności z własną refleksyjnością. W konsekwencji nastąpił wzrost zainteresowania problematyką "uczestnictwa obywatelskiego" (civic participation) i "zaangażowania obywatelskiego" (civic engagement), badającą między innymi jednostkowe poczucie politycznego sprawstwa, rozumienie polityki, subiektywne zainteresowanie uczestnictwem w polityce oraz zróżnicowanie zachowań politycznych młodzieży. W procesie socjalizacji politycznej szczególną wagę zaczęto przywiązywać do perspektywy osobistego rozwoju jednostki, w ramach którego formuje ona własny system wartości oraz rozwija tożsamość jednostkową ${ }^{38}$. Zmianie perspektywy badawczej towarzyszyło wyjście poza naturalistyczną ontologię i zakwestionowanie funkcjonalistycznego podejścia do socjalizacji politycznej, które zawężało refleksję nad stawaniem się obywatelem do kwestii utrzymania systemu społecznego i kontynuacji istniejącego porządku politycznego. Zdaniem krytyków funkcjonalizmu, czyniło to z socjalizacji politycznej proces jednostronnej i odgórnej indok-

${ }^{36}$ J. Torney-Purta, J.A. Amadeo, M.W. Andolina, A Conceptual Framework and Multimethod Approach for Research on Political Socialization and Civic Engagement, [w:] Handbook of Research on Civic Engagement in Youth, red. L.R. Sherrod, J. Torney-Purta, C.A. Flanagan, New Jersey 2010, s. 499.

${ }^{37}$ K.M. Jenning, Political Socialization, [w:] The Oxford Handbook of Political Behavior, red. R.J. Dalton, H.-D. Klingemann, New York 2007.

${ }^{38}$ D. Sears, Political socialization, [w:] Handbook of Political Science, red. F.I. Greenstein, N.W. Polsby, Massachusetts 1975, s. 95. 
trynacji, uniemożliwiając podjęcie $\mathrm{w}$ procesie badawczym rozpoznania kwestii władzy, dominacji i dyskryminacji ${ }^{39}$. Podejście interpretacjonistyczne (będące ontologiczną podstawą dla m.in. socjologii fenomenologicznej i interakcjonizmu symbolicznego) kierowało uwagę badaczy ku „analizom podmiotowości, sprawczości i socjologii obywatelskiej" ${ }^{40}$.

Jedną z najwcześniejszych krytyk podejścia funkcjonalistycznego były rozważania R.W. Conella z 1971 roku, oparte na założeniach psychologii rozwojowej i stojące $\mathrm{w}$ sprzeczności z ówcześnie dominującym nurtem badawczym. R. Conell zwracał uwagę na znaczenie afektywnych i społecznych aspektów rozumienia politycznego, wprost podważając funkcjonalistyczne wyjaśnienie socjalizacji politycznej, które określał mianem „podejścia linii produkcyjnej" (producation line approach). Zależność dzieci od informacji politycznych przetworzonych przez dorosłych nie oznacza, zdaniem R. Conella, że dzieci w prosty sposób reprodukują idee dorosłych. Podkreślał on, że socjalizacja polityczna nie jest pasywnym procesem, ale „świadomym i kreatywnym działaniem" młodych ludzi. Choć rozwój postaw politycznych młodzieży nie jest mechanicznie wykonywanym zadaniem, ale "procesem warunkowym i historycznym" (contingent, historical process), Conell za kwintesencję procesu socjalizacji politycznej uznawał ostatecznie międzygeneracyjny przekaz tradycji myślenia o obiektach politycznych (np. przekonań o zagrożeniu inwazją ze strony określonych narodów). Jak trafnie podsumowywał David Buckingham: „Conell dokonuje afirmacji dziecięcej oryginalności, jednocześnie jej zaprzeczając; dzieci rzeczywiście nadają [polityce - D.H.-W.] znaczenia, ale czynią to w warunkach, na które nie mają wpływu" 41 .

Interpretacjonistyczne podejście teoretyczne do analizy zjawisk politycznych pojawiło się też jako odpowiedź na zmiany społeczne i polityczne ery ponowoczesnej, wraz z wyłanianiem się społeczeństwa postindustrialnego (Daniel Bell), rozwojem postaw postmaterialistycznych (Roland Inglehart) oraz kryzysem legitymizacji w okresie późnego kapitalizmu (Jürgen Habermas ${ }^{42}$. Opierało się ono na założeniu, że kluczowa dla wyjaśnienia działań lu-

${ }^{39}$ J. Torney-Purta, J.A. Amadeo, M.W. Andolina, A Conceptual Framework, s. 500.

40 E. Hałas, Refleksyjny podmiot w świecie społecznym. O paradygmacie i założeniach socjologii interpretacyjnej, Roczniki Nauk Społecznych, 2016, 8(44), 4, s. 44.

${ }^{41}$ D. Buckingham, The Making of Citizens: Young People, News and Politics, London - New York 2000, s. 13.

${ }^{42}$ Sygnalizowaną zmianę orientacji badań w ramach socjologii polityki można umieścić w szerszym kontekście: wyłonienia się nowego paradygmatu interpretacjonistycznego, stojącego w opozycji do dominującego paradygmatu normatywnego. Wielość podejść interpretacjonistycznych spaja definicja Fritza Schütze, który interpretacjonizm w socjologii określił jako „wszystkie orientacje teoretyczne, których punktem wyjścia jest wyposażony w sens, symbo- 
dzi jest kulturowa analiza polityki, prowadzona z perspektywy intersubiektywnej - skupiającej się na ponadjednostkowych, „wspólnych znaczeniach i tożsamościach, konstytuujących symboliczną, ekspresyjną i interpretacyjną część życia społecznego"43. Centralne dla kulturowej analizy polityki było pojęcie interpretacji, odnoszących się zarówno do ukrytych, intersubiektywnych znaczeń, podzielanych przez aktorów politycznych, jak i do jawnych i uporządkowanych działań badaczy życia społecznego, zmierzających do zrozumienia i upowszechnienia tychże znaczeń. Badanie podzielanych przez jednostki i grupy interpretacji, wraz z kulturową analizą rytuałów i symboli, daje wgląd zarówno „w systemy znaczeń, jak i w strukturę i intensywność tożsamości politycznej"44. Stosunkowo wcześnie, bo już w roku 1964 Murray Edelman łączył wątki symbolizmu politycznego, rytuału politycznego oraz tożsamości zbiorowej. Jak pisał w The Symbolic Uses of Politics (1964), polityka to nic innego jak

przesuwający się korowód symboli, na które reagujemy na dwóch poziomach: kognitywnym, dotyczącym informacji, jakie przekazuje każdy symbol oraz afektywnym, składającym się z potężnych uczuć, jakie budzi symbol polityczny. Umiejętność przywódców do dostarczania symbolicznego wsparcia masom pozwala zorganizowanym grupom zabezpieczać dla siebie większą część korzyści materialnych ${ }^{45}$.

Marc Howard Ross, w jednym z najbardziej znanych esejów poświęconych kulturowej analizie polityki (Culture and Identity in Comparative Political Analysis z 1997 r.), za kluczowe uznał przyjęcie antropologicznego rozumienia kultury jako systemu publicznych znaczeń. Przedmiotem analiz kulturowych polityki miało być znaczenie symboli kulturowych dla wytwarzających je i wykorzystujących jednostek i grup społecznych. Zachowania ludzi, tworzone przez nich instytucje oraz struktury społeczne, traktowane niegdyś jako kultura sama w sobie, zaczęły być rozumiane jako „zjawiska wytwarzane kulturowo" ${ }^{\prime 4}$. W wielu obszarach nauk społecznych doszło do radykalnego przesunięcia w postrzeganiu kultury: od kultury jako zachowań do kultury jako znaczeń. Kultura (również polityczna) ujmowana zaczęła być - za Cliffordem Geertzem - jako

liczny, oparty na mowie charakter rzeczywistości społecznej; orientacje, które podkreślają, że członkowie społeczeństwa stoją stale wobec zadania interpretacji ruchów interakcyjnych partnerów w interakcji, społecznych ram interakcji i instytucjonalnych przejawów społeczeństwa" (F. Schütze, Trajektorie cierpienia jako przedmiot badań socjologii interpretatywnej, Studia Socjologiczne, 1997, 1, s. 22).

${ }^{43}$ M.H. Ross, Culture and Identity in Comparative Political Analysis, [w:] Culture and Politics.

A Reader, red. L. Crothers, Ch. Lackhart, New York 2000, s. 40.

${ }^{44}$ Tamże, s. 41.

45 Tamże, s. 53.

46 Tamże, s. 42. 
historycznie przekazywany wzór znaczeń ucieleśnionych w symbolach, system odziedziczonych pojęć wyrażonych w formach symbolicznych, za pomocą których ludzie komunikują się, utrwalają i rozwijają swoją wiedzę o życiu i postawy wobec życia ${ }^{47}$.

Stanowisko to dowartościowało znaczenie badań idiograficznych, opisujących struktury i funkcje instytucji politycznych jako swoiste, jednostkowe i niepowtarzalne wytwory ludzkiej działalności.

Kluczowe znaczenie $\mathrm{w}$ interpretacjonistycznym podejściu do polityki (w tym: do socjalizacji politycznej) pełni narracja. Jak podkreślają Mark Bevir i R.A.W. Rhodes, narracje są "dla badań politologicznych tym samym, czym teorie dla nauk przyrodniczych" ${ }^{48}$. Interpretacje to przekonania, emocje i światopoglądy leżące u podstaw działania ludzi. Narracje z kolei stanowią bardziej dostępne poznaniu, werbalne i niewerbalne wyrazy tychże, leżących u podstaw działania ludzi, interpretacji. Narracje czerpią ze wspólnych, konstruowanych w codziennym doświadczeniu i współdzielonych z członkami danej zbiorowości sposobów rozumienia świata. Wyjaśnienie ludzkiego działania wymaga sięgnięcia do psychokulturowych ${ }^{49}$ narracji, będących społecznie konstruowanymi wyjaśnieniami zdarzeń, zawierającymi przekonania, dyskursy oraz idee wykorzystywane (i komunikowane) przez ludzi. Moc wyjaśniająca narracji nie leży w ich prawdziwości bądź fałszu, ale w „ich sile emocjonalnej i uprawdopodobnieniu w konkretnych kontekstach politycznych" ${ }^{50}$. Zrozumienie działań, praktyk oraz instytucji politycznych możliwe jest dzięki odkrywaniu - zawartych w strukturze narracyjnej - znaczeń, preferencji i przekonań. Narracje, niczym utwory literackie, dają badaczowi wgląd w jednostkowe i zbiorowe opowieści, osadzone w określonym miejscu i czasie, wypełnione postaciami, wydarzeniami i emocjami. W przeciwieństwie jednak do literackiej fikcji, w "opowieściach nauk humanistycznych” struktury narracyjne powiązane są z obiektywną wiedzą o świecie ${ }^{51}$.

Narracje pełnią istotne i zróżnicowane role w życiu politycznym. Najczęstszą z nich jest rola zwierciadła, odbijającego głęboko zakorzenione przekonania kulturowe. Przykładem tej narracyjnej roli mogą być zawarte w podręcznikach opisy historii narodowej oraz symboli narodowych. Narracje mogą też

47 C. Geertz, The Interpretation of Culture. Selected Essays, New York 1973, s. 89.

${ }^{48}$ M. Bavir, R.A.W. Rhodes, Teoria interpretacjonistyczna, [w:] Teorie i metody w naukach politycznych, red. D. Marsh, G. Stoker, Kraków 2006, s. 134.

49 M. Ross używa określenia „psycho-kulturowa narracja”, aby połączyć poziom indywidualnych procesów psychologicznych, kluczowych w konstruowaniu interpretacji, z poziomem dynamiki kulturowej, nadającej indywidualnym orientacjom wymiar kolektywny. W ten sposób podkreśla on, iż orientacje nie mają wyłącznie osobistego charakteru, ale są wzmacniane społecznie, łącząc jednostki w procesie zbiorowego wytwarzania znaczeń (M.H. Ross, Culture and Identity, s. 45).

50 M.H. Ross, Culture and Identity, s. 46.

${ }^{51}$ M. Bavir, R.A.W. Rhodes, Teoria interpretacjonistyczna, s. 134. 
- zależnie od kontekstu - pełnić funkcje katalizatora albo inhibitora, potęgując bądź redukując konflikty między- i wewnątrzgrupowe w społeczeństwie. Tego typu eskalującymi albo wyciszającymi konflikt narracjami mogę być na przykład opowieści o zagrożeniach, jakie niesie ze sobą imigracja albo (powieściowe, filmowe bądź medialne) opowieści o zróżnicowaniu kulturowym jako pozytywnym źródle równowagi, współpracy społecznej i obopólnych zysków. Narracja może także stanowić pośredni czynnik sprawczy działania, kiedy zawarta w niej interpretacja wydarzenia ukierunkowuje przyszłe działanie polityczne, wyznaczając możliwe pola aktywności bądź zaniechania działania. Jak podkreśla M. Ross: „Politycznie znaczące narracje zawierają relacje dotyczące zarówno kolektywnych lęków i zagrożeń dla tożsamości, jak i przywoływanych z przeszłości heroicznych czynów i triumfów" ${ }^{\prime 2}$. Nowe narracje odwołują się do już istniejących; stale ewoluują, a pewne ich wątki tracą bądź zyskują na emocjonalnej intensywności.

Podejście interpretacjonistyczne $\mathrm{w}$ badaniach rozumienia polityki przez młodzież również wyrosło na gruncie postmodernistycznej krytyki behawioralnych analiz politycznych, utrzymujących, że „systemy społeczne nie składają się z jednostek ludzkich, lecz z ról" ${ }^{23}$. Podkreślano znaczenie namysłu nad tym, w jaki sposób różne grupy młodzieży rozumieją działanie społeczne i polityczne; w jaki sposób znaczenia polityki są przez młodych ludzi społecznie konstruowane i negocjowane. Skupiano się na interpretacjach, jakie młodzi ludzie formułują względem norm, wartości i politycznych wzorów zachowań. Zrezygnowano przy tym z normatywnej oceny młodzieżowych interpretacji, zmierzającej wcześniej do nadawania im statusu odbiegających od albo adekwatnych względem standardów osób dorosłych. Młodzieżowe interpretacje zjawisk politycznych, symboli i rytuałów miały być traktowanie jako samoistne i uprawnione. Przekonanie to wydawało się szczególnie adekwatne w kontekście przyspieszającej zmiany społecznej, odwróconej perspektywy socjalizacyjnej, a także fundamentalnego pytania o zmieniającą się naturę obywatelstwa we współczesnych społeczeństwach ${ }^{54}$. Obecne w podejściu interpretacjonistycznym założenie refleksyjności podmiotu odwoływało się do podmiotowej władzy nazywania, zdolności nadawania znaczeń obiektom (także politycznym) w świecie, a w konsekwencji - poszukiwania i konstruowania tożsamości ${ }^{55}$.

Ontologicznie, podejście interpretacjonistyczne skupia się na „ludzkim wymiarze" działań społecznych, odrzucając przekonanie, że zachowania polityczne są całkowicie zdeterminowane przez struktury. Zauważa się w nim

\footnotetext{
${ }^{52}$ M.H. Ross, Culture and Identity, s. 47.

${ }^{53}$ G. Almond, G.B. Powell, System polityczny, jego otoczenie, s. 26.

${ }^{54}$ D. Buckingham, The Making of Citizens, s. 14.

${ }^{55}$ E. Hałas, Refleksyjny podmiot, s. 44.
} 
znaczenie indywidualnych motywacji działania, a nie bezrefleksyjnego spełniania oczekiwań społecznych. Działania grup młodzieży i znaczenia, jakie nadają one zjawiskom politycznym, są osadzone $w$ procesie socjalizacji i strukturze społecznej, w której wzrastają. Młodzi ludzie są jednak zdolni do działania innowacyjnego i kreatywnej adaptacji. Punktem wyjścia dla zrozumienia procesów socjalizacji politycznej jest uwzględnienie perspektywy działających podmiotów - uczestników systemu politycznego, którzy w codziennych interakcjach i procesie komunikowania się podejmują aktywne działania, konfrontując się z oczekiwaniami społecznymi, dokonując interpretacji sytuacji politycznych oraz negocjując swoje role w ramach instytucji społecznych i politycznych. Czynią to z zamiarem autonomicznego kształtowania własnej tożsamości.

Jak podkreśla się z perspektywy interakcjonizmu symbolicznego ${ }^{56}$, „pole interpretacji jest wyraźnie ograniczone ${ }^{\prime \prime 57}$ w sytuacji, gdy oczekiwania co do ról (czyli definicje ról) są z góry określone, a młodym ludziom wpaja się - w procesie socjalizacji politycznej - określony zestaw społecznie aprobowanych idei, działań i zachowań politycznych. Jednakże, między unormowanymi oczekiwaniami co do zachowań a niepowtarzalnością kreowanej $\mathrm{w}$ procesie samointerpretacji biografii otwiera się przestrzeń negocjowania własnego ,ja”. Jest ono z perspektywy interakcjonistycznej rozumiane jako nieprzerwany i oparty na autorefleksji proces osiągania równowagi między tożsamością społeczną (oczekiwaniami społecznymi) a tożsamością osobową (niepowtarzalnością własnej biografii) ${ }^{58}$. Społeczne konstruowanie takich pojęć, jak między innymi ",aktywne obywatelstwo", , demokratyczne obywatelstwo" czy „obywatelstwo narodowe" również wpisane jest w proces osiągania "tożsamości »ja«" (Ich-Identität), rozumianej według Jürgena Habermasa jako „równowaga pomiędzy utrzymywaniem obydwu tożsamości, osobistej i społecznej" 59 . Ciągła potrzeba interpretacji ról (czyli podejmowania działań zgodnie bądź niezgodnie z definicjami tychże ról), zmierzająca do pogodzenia społecznego i biograficznego wymiaru własnej tożsamości, ma szczegól-

${ }^{56}$ Interakcjonistyczna teoria socjalizacji wpisuje się $\mathrm{w}$ nurt interpretacyjny $\mathrm{w}$ naukach społecznych. Jak słusznie podkreśla E. Hałas: „Orientacja badawcza, dla której przyjęto etykietę »interakcjonizm symboliczny «, użytą w 1937 r. przez Herberta Blumera, uchodząca za podstawę paradygmatu interpretacyjnego, była i pozostaje bardzo zróżnicowanym środowiskiem badawczym, i to o charakterze interdyscyplinarnym" (E. Hałas, Refleksyjny podmiot, s. 42). s. 146.

${ }^{57}$ K.-J. Tillmann, Teorie socjalizacji. Społeczność, instytucja, upodmiotowienie, Warszawa 1996,

${ }^{58}$ Tamże, s. 147.

59 J. Habermas, Stichworte zu einer Theorie der Sozialisation, [w:] Kultur und Kritik, red. J. Habermas, Frankfurt a. Main 1973, s. 131, za: K.-J. Tillmann, Teorie socjalizacji, s. 147. 
ne, ponadjednostkowe znaczenie dla trwałości systemów politycznych. Jak podkreśla Elżbieta Hałas (za Norbertem Wileyem),

rozróżnienie między jaźnią (self) i tożsamością niosło istotne konsekwencje dla rozwoju demokracji, gdyż u podstaw zróżnicowanych tożsamości pozostawały uniwersalne możliwości jaźni jako warunek równości w porządku demokratycznym ${ }^{60}$.

Warto przywołać w tym kontekście pojęcie "stabilnej osobowości" (Selbst), stanowiące - zdaniem J. Habermasa - składnik normatywny procesu socjalizacji i cel rozwoju podmiotowego w perspektywie interakcyjnej. Jak podkreślał J. Habermas w tekście zatytułowanym Stichworten zur Theorie der Sozialisation („Hasła teorii socjalizacji”) ${ }^{61}$, wykształcenie stabilnej osobowości wymaga rozwinięcia podstawowych kwalifikacji do działania w rolach. Są to: tolerancja na frustrację (w sytuacji ambiwalencji ról i niemożliwości zaspokojenia własnych potrzeb), tolerancja na wieloznaczność (akceptacja konieczności ciągłej interpretacji oczekiwań co do ról, które są niejednoznaczne) oraz dystans wobec ról (zdolność refleksyjnego ustosunkowania się do ról, czyli wydawania ocen i interpretacji, w celu osiągnięcia autonomii).

W zarysowanym powyżej mikrosocjologicznym wymiarze analiz procesów socjalizacji J. Habermas wyznaczył „punkty zaczepienia” dla analiz makrospołecznych, podejmowanych z perspektywy panowania społecznego. Trzy wymiary panowania społecznego to: represyjność ról (dążenie systemu społecznego/instytucji społecznej do stanu komplementarności pomiędzy oczekiwaniami co do ról a potrzebami podmiotów), sztywność ról (ograniczanie w systemie społecznym/instytucji społecznej samoreprezentacji podmiotów i narzucanie jednej właściwej interpretacji roli) oraz społeczna kontrola zachowań (systemowe bądź instytucjonalne ograniczenie albo wykluczenie możliwości dystansowania się wobec ról, skutkujące brakiem autonomii podmiotów). Wypracowane przez J. Habermasa pojęcia "tożsamości »ja «" i „społecznego zakotwiczenia podmiotowości" (Subjekthaftligkeit) mają kluczowe znaczenie dla analizy procesów socjalizacji, integrując dwa główne wymagania względem rozumienia podmiotu. Jak podkreśla Klaus-Jürgen Tillmann,

teoria ta, z jednej strony, jest w stanie przedstawiać socjalizację jako jedność uspołecznienia i indywidualizacji, z drugiej zaś ukazuje podmioty jako aktywnie działające i współkształtujące swój własny rozwój. Ponadto wywody Habermasa o represyjnych strukturach systemów rol pozwalają stwierdzić, że za pomocą tego podejścia można połączyć rozwój tożsamości z warunkami społecznymi, w które systemy ról są wpisane $^{62}$.

\footnotetext{
${ }^{60}$ E. Hałas, Refleksyjny podmiot, s. 44-45.

${ }^{61}$ Por. J. Habermas, Stichworte zu einer Theorie.

${ }^{62}$ K.-J. Tillmann, Teorie socjalizacji, s. 152-153.
} 


\section{Model socjalizacji politycznej w przebiegu życia (a life-course model of political socialization)}

Jak uwydatniają czołowe badaczki socjalizacji politycznej i zaangażowania obywatelskiego młodzieży, Lonnie R. Sherrod, Judith Torney-Purta i Constance Flanagan, szczególnie obiecującą, teoretyczną perspektywą badań nad socjalizacją polityczną jest model wypracowany jako połączenie nauk politycznych i perspektywy psychologii rozwojowej, umożliwiający szeroką konceptualizację zarówno socjalizacji politycznej, jak i uczestnictwa obywatelskiego (wzorów obywatelstwa) młodzieży ${ }^{63}$. Zmiana paradygmatyczna w obszarze psychologii rozwojowej, zapoczątkowana na przełomie lat 60. i 70. XX wieku w związku z wyłonieniem się nowej orientacji teoretycznej life-span (termin rozpowszechniony w psychologii) albo life-course (termin rozpowszechniony w socjologii), wpłynęła również na inne nauki społeczne. Również w socjologii polityki dokonał się zwrot w myśleniu o człowieku, mechanizmach jego rozwoju psychospołecznego, sposobach adaptacji do świata społecznego i uczenia się ról społecznych. Holistyczna i interdyscyplinarna perspektywa rozwoju człowieka w pełnym cyklu życia opierała się na kilku założeniach, kluczowych również dla badań socjalizacji politycznej i zaangażowania obywatelskiego młodzieży:

1) założenia o całożyciowym rozwoju psychicznym człowieka i traktowaniu struktury rozwoju człowieka jako zdarzenia całościowego, złożonego z jednakowo ważnych etapów. Przyjęcie tego założenia podważało dotychczas dominujące, rozwijane od czasów Z. Freuda czy J. Piageta stanowisko, zakładające jednolity i jednokierunkowy proces rozwoju ludzkiego, kończący się zasadniczo po ustaniu fazy adolescencji, wraz z wejściem $\mathrm{w}$ dorosłość ${ }^{4}$. Jak podkreśla Maria Straś-Romanowska:

Teza o nieustającej przemianie człowieka skłoniła równocześnie badaczy do weryfikacji tradycyjnego poglądu o bezwzględnym wpływie doświadczeń z wcześniejszych okresów życia jednostki na przebieg całego jej rozwoju oraz na formę jej życia w dorosłości ${ }^{65}$;

2) założenia o wielowymiarowości (różnorodności wzorców rozwojowych) oraz wielokierunkowości (progresywnym bądź regresywnym kierunku zmian) rozwoju człowieka. Założenie to doprowadziło do odejścia od

${ }^{63}$ L.R. Sherrod, J. Torney-Purta, C. Flanagan, Research on the Development of Citizenship: A Field Comes of Age, [w:] Handbook of Research on Civic Engagement in Youth, red. L.R. Sherrod, J. Torney-Purta, C.A. Flanagan, New Jersey 2010, s. 2.

${ }^{64}$ Tamże, s. 3.

${ }^{65}$ M. Straś-Romanowska, I Kongres Psychologów Life-Span: Między psychologia rozwojowa a psychologia rozwoju, Przegląd Psychologiczny, 2001, 44, s. 94. 
postrzegania rozwoju struktur psychicznych i zachowania ludzkiego jako monolitycznego, powszechnego, deterministycznego i uniwersalnego procesu „zmian wyłącznie progresywnych”66.

3) założenie o intraindywidualnej plastyczności, oznaczającej zróżnicowanie stopnia podatności psychiki ludzkiej na modyfikacje w zależności od indywidualnych doświadczeń życiowych. Dotychczasowe skupienie na reaktywności człowieka $\mathrm{w}$ procesie rozwojowym ustąpiło miejsca perspektywie aktywności i uczestnictwa jednostki we własnym procesie rozwoju, którego indywidualizacja "wykazuje tendencję do nasilania się wraz z wiekiem jednostki" ${ }^{67}$. Przekonanie o całożyciowej plastyczności postaw politycznych obecne jest również $\mathrm{w}$ badaniach $\mathrm{z}$ zakresu socjologii polityki ${ }^{68}$;

4) założenie o konieczności uwzględnienia w badaniach procesów rozwoju człowieka zjawisk właściwych dla okresu historycznego (warunków społeczno-kulturowych, ekonomicznych, politycznych i przyrodniczych), wpływających pośrednio i niejednoznacznie na całożyciowe mechanizmy rozwoju człowieka. Kluczowa w tym założeniu była świadomość wzajemności oddziaływań jednostki i świata: wpływ czynników makrospołecznych na rozwój człowieka równoważony jest przez wpływ aktywności rozwojowej jednostki na swoje otoczenie społeczne. Obok presji na adaptację i kontynuację społeczno-kulturową uwzględnić też należy perspektywę indywidualnego rozwoju, pozwalającą na uwzględnienie (również w procesie socjalizacji politycznej) aspektu moralnego - „jednostce przypisuje się bowiem odpowiedzialność zarówno za bieg własnego życia, jak i za los kultury oraz cywilizacji" ${ }^{69}$;

5) założenie o wpływie na rozwój człowieka nie tylko czynników związanych z wiekiem chronologicznym (kondycja biologiczna i zadania rozwojowe) oraz normatywnych czynników związanych z wpływami historycznymi (warunki cywilizacyjne, transformacje polityczne i ekonomiczne, wojny, niepokoje społeczne), ale także czynników pozanormatywnych (non-normative influence). Te ostatnie są biologicznymi i środowiskowymi wydarzenia$\mathrm{mi}$, nie powiązanymi bezpośrednio $\mathrm{z}$ wiekiem chronologicznym jednostki bądź doświadczanym przez nią kontekstem społeczno-kulturowym. Czynniki pozanormatywne mają charakter idiosynkratyczny i mogą być zarówno wydarzeniami losowymi (jak wypadek samochodowy), jak i zdarzeniami wynikającymi z intencjonalnego i autonomicznego działania jednostki (jak

${ }^{66}$ J. Trempała, Natura rzowoju psychicznego, [w:] Psychologia rozwoju człowieka, red. J. Trempała, Warszawa 2011, s. 48.

${ }^{67}$ M. Straś-Romanowska, I Kongres Psychologów Life-Span, s. 95.

${ }^{68}$ Por. D.F. Alwin, J.A. Krosnick, Aging, Cohorts, and the Stability of Sociopolitical Orientations over the Life Span, The American Journal of Sociology, 1991, 97, s. 169-195.

${ }^{69}$ M. Straś-Romanowska, I Kongres Psychologów Life-Span, s. 96. 
rozwód, migracja bądź radykalna zmiana kariery zawodowej ${ }^{70}$. Rozwój psychospołeczny stanowi wypadkową dyspozycji biologicznych, kontekstu społeczno-kulturowego oraz nieprzewidzianych wydarzeń i aktów wolitywnych działających podmiotów. Obok czynników genetycznych to właśnie czynniki pozanormatywne, jak podkreśla M. Straś-Romanowska:

decydują w głównej mierze o unikalności i nieprzewidywalności drogi życiowej jednostki; podważają tym samym sens ustanawiania uniwersalnych norm rozwojowych, zwłaszcza dla osób w okresie dorosłości i późnej dorosłości ${ }^{71}$;

6) założenie o interdyscyplinarnym charakterze badań nad rozwojem człowieka w pełnym cyklu życia, skutkujące poszerzeniem horyzontu badawczego i wykorzystaniem powiązań z innymi dyscyplinami społecznymi $\mathrm{w}$ celu pełnego zrozumienia struktury i dynamiki ludzkiego życia.

Jak podkreślają L. Sherrod, J. Torney-Purta oraz C. Flanagan: „Kwestie plastyczności i całożyciowej perspektywy rozwojowej również znajdują się w polu zainteresowań nauk politycznych, w ramach badań nad socjalizacją polityczną"72. Perspektywa life-course w badaniach nad socjalizacją polityczną zakładała przedefiniowanie podejścia do człowieka jako podmiotu socjalizacji. Perspektywa ta akcentowała wielość, całożyciowy charakter i otwartość (możliwość modyfikacji narzuconego celu) ścieżek rozwojowych i rezultatów procesu socjalizacji. W interakcjach jednostki ze środowiskiem obok wpływu instancji socjalizacyjnych oraz określonego kontekstu społeczno-politycznego i historycznego decydujące znaczenie miała autonomia podmiotu, współtworzącego własny rozwój.

Interdyscyplinarna perspektywa life-course przyjęta została przez Philo C. Wasburn i Tawny J. Adkins Covert, autorki Making Citizens. Political Socialization Research and Beyond z 2017 roku, które zaproponowały model socjalizacji politycznej zmierzający do integracji istniejących już podejść. Badaczki uwzględniły w swoim modelu cztery dotychczas dominujące perspektywy teoretyczne w badaniach nad socjalizacją polityczną. Najwcześniejszą była perspektywa trwania (persistence perspective), opierająca się na założeniu, iż zasadnicze zręby orientacji politycznych kształtują się na wczesnym etapie rozwoju człowieka, a ich wyróżniającą cechą jest trwałość na późniejszych etapach życia. Założenie to, nazwane przez Donalda Searinga i współpracowników zasadą pierwszeństwa (primary/primacy principle) mówi, że pewne orientacje polityczne, wykształcone w okresie dzieciństwa i wczesnej ado-

70 Por. P.B. Baltes, Life-span developmental psychology: Some converging observations on history and theory, [w:] Life-span development and behavior, red. P.B. Bates, O.G. Brim, New York 1979.

71 M. Straś-Romanowska, I Kongres Psychologów Life-Span, s. 96.

${ }^{72}$ L.R. Sherrod, J. Torney-Purta, C. Flanagan, Research on the Development, s. 3. 
lescencji mają tendencję do trwania przez całe późniejsze życie jednostki ${ }^{73}$. Dotyczy to między innymi poczucia politycznego sprawstwa, nabytego na etapie socjalizacji pierwotnej w wyniku między innymi udziału dzieci w rodzinnym podejmowaniu decyzji ${ }^{74}$ oraz wysokiego poziomu zainteresowania rodziców polityką ${ }^{75}$. Zwolennicy tej perspektywy wskazywali też w swoich badaniach na trwałość kształtowanego na etapie wtórnej socjalizacji szkolnej (np. poprzez udział dzieci $\mathrm{w}$ demokracji szkolnej i głosowaniach) poczucia lojalności wobec narodu i świadomości obowiązków obywatelskich ${ }^{76}$. W perspektywie trwania kładziono nacisk na rozwój tych orientacji politycznych, które przyczyniają się do stabilności i trwałości systemów politycznych.

Antytezą perspektywy trwania była perspektywa całożyciowej otwartości na wpływy (the lifetime openness perspective), podważająca tezę o wieku jako decydującym czynniku nabycia, utrzymania bądź zmiany orientacji politycznej. Opierała się ona na przekonaniu, że orientacje polityczne ludzi są odbiciem ich aktualnych doświadczeń socjalizacyjnych w ramach sprawowanych ról (w rodzinie, szkole, pracy, działalności społecznej itp.) $)^{77}$. Jak podkreślali M. Jennings i Richard G. Niemi, zmiana orientacji politycznej może, ale nie musi, przybierać formy świadomej, celowej reakcji na przekształcenia, zachodzące $\mathrm{w}$ osobistym i politycznym otoczeniu podmiotu. Zakłócenia dotychczasowej orientacji politycznej mogą pojawiać się - z uwagi na jej słabe zakorzenienie - w przypadkowy, efemeryczny i nieuświadomiony sposób ${ }^{78}$.

Pomiędzy sygnalizowanymi powyżej, biegunowo usytuowanymi perspektywami całożyciowej stabilności oraz całożyciowej otwartości na zmianę znajdują się dwa podejścia do socjalizacji politycznej, przyjmujące względną trwałość orientacji politycznych, przy ich jednoczesnej podatności na przekształcenia, ale w określonych warunkach i na określonych etapach życia. Pierwsza z nich, perspektywa okresów podatności na wpływy (the impressionable years perspective), wyłoniła się w ramach amerykańskich badań generacyjnych. Zamiarem ich było ustalenie znaczenia kontekstu społeczno-historycz-

${ }^{73}$ D.D. Searing, G. Wright, G. Rabinowitz, The Primacy Principle: Attitude Changes and Political Socialization, British Journal of Political Science, 1976, 6, s. 83-118.

${ }^{74}$ Por. R.E. Lane, Political Maturation in the United States and Germany, [w:] Political Man, red. R.E. Lane, New York 1972, s. 77-93.

${ }^{75}$ D. Marvick, Ch.R. Nixon, Recruitment Contrast in Rival Campaign Groups, [w:] Political Decision Makers, red. D. Marvick, New York 1961, s. 200-2017; S. Verba, K. Lehman Schlozman, N. Burns, Family Ties: Understading the Intergenerational Transmission of Political Participation, [w:] The Social Logic of Politics, red. A.S. Zuckerman, Philadelphia 2005.

${ }^{76}$ D. Easton, J. Dennis, Children in the Political System; R.D. Hess, J.V. Torney, The Development of Political Attitudes; D.E. Campbell, Why We Vote: How Schools and Communities Shape Our Civic Life, Princeton 2006.

77 P.C. Wasburn, T.J. Adkins Covert, Making Citizens, s. 7.

${ }^{78}$ M.K. Jennings, R.G. Niemi, Generations and Politics: A Panel Study of Young Adults and Their Parents, Princeton - New Jersey 1981, s. 20. 
nego (wydarzeń takich jak wojny, kryzysy gospodarcze, kryzysy polityczne, rewolucje, radykalne zmiany władzy) na grupy osób w podobnym wieku i na podobnym etapie życia, połączonych wspólnotą doświadczeń pokoleniowych (cohort or generational effect) ${ }^{79}$. W podejściu tym przyjęto, że późna adolescencja i wczesna dorosłość to okresy życia szczególnie krytyczne dla rozwoju trwałych orientacji politycznych (impressionable years hypothesis). Nie zaskakuje, iż upowszechniła się $\mathrm{w}$ okresie zmian politycznych lat 60. i 70. XX wieku, z czym wiąże się szereg kontrowersji, między innymi krytyka nadmiernego skupienia na badaniu środowisk zaangażowanych w kontrkulturowe, młodzieżowe ruchy polityczne końca lat 60 . XX wieku, a przez to - zaburzenie obiektywności i możliwości uogólnienia wyników badań na mniej zaangażowanych politycznie członków grupy wiekowej/ pokolenia ${ }^{80}$.

Drugim podejściem do socjalizacji politycznej, akcentującym współistnienie mechanizmów kontynuacji i zmiany, jest perspektywa cyklu życia (the life cycle perspective). Wyrosła na gruncie badań nad zaangażowaniem politycznym osób starszych, prowadzonych w latach 70. i 80. XX wieku, a także w latach dwutysięcznych. Wskazywały one na kształtowanie się w tej grupie wiekowej nowych znaczeń ideologicznych w zmienionym kontekście społeczno-historycznym, skutkujące rozwojem innych - nierzadko diametralnie różnych od nabytych w młodości - orientacji politycznych na późniejszych etapach życia ${ }^{81}$. Szukając powiązań między procesami starzenia się a rozwojem dyspozycji politycznych (aging and political disposition), część badań wskazuje na fakt, iż pewne dyspozycje polityczne rozwijają się $\mathrm{w}$ określonych stadiach cyklu życia ${ }^{82}$. Ogólnie rzecz ujmując, podejście to zwraca uwagę na znaczenie tranzycji ról społecznych i kolejności tychże ról (the sequence of roles) w cyklu życia w analizach procesu socjalizacji politycznej. Ponadto, na rezultat socjalizacji politycznej w okresie tranzycji ról społecznych - od roli ucznia, poprzez rolę studenta, współmałżonka, pracownika, rodzica, aż do roli emeryta i osoby starszej - wpływa też kontekst społeczno-historyczny, w jakim dane przejście ma miejsce. Oczekiwania i żądania wobec społeczeństwa oraz systemu politycznego ulegają restrukturyzacji wraz ze zmianą potrzeb na poszczególnych etapach życia (w cyklu życia); jednocześnie, zmieniające się

79 Tamże, s. 122.

${ }^{80}$ P.C. Wasburn, T.J. Adkins Covert, Making Citizens, s. 8.

${ }^{81}$ Przykładem może być badanie zachowań wyborczych starszych Amerykanów, wskazujące m.in. na poparcie dla socjaldemokratycznej polityki zdrowotnej, oznaczające dla wielu odejście od dotychczasowej, zdecydowanie konserwatywnej orientacji politycznej (Por. L.R. Jacobs, T. Skocpol, Health Care Reform and American Politics: What Everyone Needs to Know, Oxford 2012).

82 M.M. Braungart, Aging and Politics, Journal of Political and Military Sociology, 1984, 12; J.S. Steckenrider, N.E. Cutter, Aging and Political Socialization: The Importance of Roles and Transitions, [w:] Political Learning in Adulthood, red. R.S. Sigel, Chicago, s. 56-88. 
oczekiwania wobec systemu politycznego stanowią odbicie struktury społecznej, w jakiej przychodzi jednostkom funkcjonować ${ }^{83}$.

Żadna z czterech powyżej zasygnalizowanych perspektyw nie uzyskała statusu dominującego paradygmatu, integrującego teorię i badania nad socjalizacją polityczną. Ich założenia należy jednak potraktować jako uzupełniające, a nie wzajemnie się wykluczające, co daje szansę na lepsze, holistyczne zrozumienie procesów stawania się obywatelem. Każde z zaprezentowanych podejść teoretycznych stanowi jeden z kadrów, składających się na całościowy obraz procesu socjalizacji politycznej. P.C. Wasburn i T.J. Adkins Covert przyjęły ogólne założenie, iż proces politycznego uczenia się jest dynamiczny i zawiera w sobie zarówno oczekiwanie kontynuacji, jak i potencjał zmiany. Przedstawiony na rycinie 1 model socjalizacji politycznej w przebiegu życia/cyklu życia (the life course model) stanowi szeroką ramę pojęciową, której osią jest spojrzenie na socjalizację polityczną jako na całożyciowy projekt jednostki. Jest ona złożonym procesem, na który wpływa szerszy kontekst historyczny i społeczny. Pierwszy stanowią makropolityczne i gospodarcze warunki w danym okresie historycznym. Kontekst społeczny socjalizacji politycznej odnosi się do istniejącej w danym miejscu i czasie struktury społecznej oraz specyfiki działalności agend socjalizacyjnych, takich jak rodzina, szkoła, grupa rówieśnicza, kościół, miejsce pracy, organizacja społeczna, czy media ${ }^{84}$.

Obok zasady pierwszeństwa i zasady lat podatności na wpływy wymieniana jest jeszcze trzecia zasada, wyprowadzana $\mathrm{z}$ istniejących już wcześniej podejść teoretycznych do socjalizacji politycznej. Jest to zasada strukturyzacji, odnosząca się do założenia o względnej trwałości orientacji politycznych w trakcie trwania życia jednostki i wpływie, jaki wewnętrzna dynamika struktury społecznej wywiera na działania polityczne członków danego społeczeństwa. Można w tym kontekście przywołać pogląd Jana Szczepańskiego, którego zdaniem wychowanie (kwintesencja procesu socjalizacji, także politycznej) jest procesem ukierunkowanym na przekazanie i wzmocnienie zasad strukturyzacji ładu społecznego. Struktury społeczne (i polityczne) powstają, powielają się i są wykorzystywane przez działające podmioty oparte na bezustannie uruchamianym mechanizmie kategoryzacji społecznej. W procesie strukturyzacji dochodzi do ograniczenia własnej odrębności jednostki na rzecz mechanizmów tworzenia tożsamości zbiorowych $^{85}$.

${ }^{83}$ R.S. Sigel, M.B. Hoskin, Perspectives on Adult Political Socialization: Areas of Research, [w:] Handbook of Political Socialization, red. S.A. Renshon, New York 1977; P.C. Wasburn, T.J. Adkins Covert, Making Citizens, s. 9.

${ }^{84}$ P.C. Wasburn, T.J. Adkins Covert, Making Citizens, s. 11.

${ }^{85}$ Por. J. Szczepański, O indywidualności, Warszawa 1988. 


\begin{tabular}{|c|c|c|c|c|}
\hline \multicolumn{5}{|c|}{$\begin{array}{c}\text { KONTEKST HISTORYCZNY } \\
\text { TOŻSAMOŚCI SPOŁECZNE (płeć, rasa/etniczność, warstwa społeczne) } \\
\text { DOJRZEWANIE (rozwój poznawczy i uzyskiwanie sprawności politycznej) }\end{array}$} \\
\hline Dzieciństwo & Adolescencja & $\begin{array}{l}\text { Wczesna } \\
\text { dorosłość }\end{array}$ & Dorosłość & Starość \\
\hline $\begin{array}{l}\text { rodzina pochodzenia } \\
\text { szkoła } \\
\text { kościót } \\
\text { stowarzyszenia } \\
\text { media }\end{array}$ & $\begin{array}{l}\text { rodzina pochodzenia } \\
\text { szkoła } \\
\text { kościół } \\
\text { stowarzyszenia } \\
\text { media }\end{array}$ & $\begin{array}{l}\text { rodzina pochodzenia } \\
\text { rodzina prokreacji } \\
\text { kościół } \\
\text { miejsce pracy } \\
\text { stowarzyszenia } \\
\text { media }\end{array}$ & $\begin{array}{l}\text { rodzina pochodzenia } \\
\text { rodzina prokreacji } \\
\text { kościół } \\
\text { miejsce pracy } \\
\text { stowarzyszenia } \\
\text { media }\end{array}$ & $\begin{array}{l}\text { rodzina prokreacji } \\
\text { kościół } \\
\text { stowarzyszenia } \\
\text { media }\end{array}$ \\
\hline \multicolumn{5}{|c|}{$\begin{array}{l}\text { ZASADA LAT PODATNOŚCI NA WPŁYWY } \\
\text { (IMPRESSIONABLE YEARS PRINCIPLE) } \\
\text { ZASADA STRUKTURYZACJI }\end{array}$} \\
\hline
\end{tabular}

Ryc. 1. Model socjalizacji politycznej w przebiegu życia

(źródło: P.C. Wasburn, T.J. Adkins Covert, Making Citizens. Political Socialization Research and Beyond, Cham 2017, s. 17)

\section{Podsumowanie}

Teresa Sasińska-Klas zwraca uwagę na pewną dysproporcję pomiędzy rozwojem makro- i mikropoziomu teoretycznego w studiach nad socjalizacją polityczną. Poziom makroteoretyczny, stanowiący między innymi przestrzeń dla sformułowania operacyjnie użytecznych hipotez, wymaga teoretycznego uporządkowania. Stanowi on - zdaniem Badaczki - jedynie „zbiór ogólnych wskazówek do badań oraz sugestie, gdzie i czego należałoby szukać, aby uczynić dalsze studia (...) bardziej owocnymi" 86 , a nie w pełni rozwiniętą makroteorię socjalizacji politycznej. Z kolei, na poziomie mikroteoretycznym $\mathrm{w}$ przedmiocie poznania procesu socjalizacji politycznej uczyniono bardzo wiele; "głównie w latach sześćdziesiątych i siedemdziesiątych przeprowadzono wiele badań empirycznych nad tym zagadnieniem i obfitość materiału empirycznego jest tu uderzająca" ${ }^{87}$. Z analiz materiału empirycznego wynika, iż prowadzone badania miały jednak $\mathrm{w}$ większości charakter ateoretyczny i ograniczały się do deskryptywnego opisu, między innymi orientacji politycznych dzieci i młodzieży, ich zainteresowań politycznych, bądź stosunku do ideologii wśród adolescentów. Jak podkreśla T. Sasińska-Klas, autorzy wielu badań „nie sięgali głębiej do teoretycznych analiz i nie próbowali

\footnotetext{
${ }^{86}$ T. Sasińska-Klas, Socjalizacja polityczna, s. 18.

87 Tamże, s. 19.
} 
- z uwzględnieniem szerszej teoretycznej perspektywy - szukać wyjaśnienia mechanizmów procesu socjalizacji politycznej" ${ }^{\prime 88}$. Celem badań nie było opracowanie paradygmatu socjalizacji politycznej, ale analiza wybranego wymiaru socjalizacji politycznej, odwołując się do ustaleń ogólnej teorii socjalizacji. Badaczka krytycznie konstatuje, iż przyjęcie podejścia ateoretycznego spowodowało, iż w miarę rozwoju socjalizacji politycznej jako subdyscypliny w naukach społecznych „utracono wiele wartościowego materiału empirycznego, ponieważ nie pogłębiano analizy uzyskanych wyników" ${ }^{\prime 29}$.

Dla zrozumienia procesu socjalizacji politycznej kluczowe wydaje się pytanie, dlaczego pewne poglądy obywateli względem wybranych aspektów życia politycznego, a także przyjmowane przez nich definicje ról w systemie politycznym zachowują całożyciową trwałość, a inne - podatne są na przekształcenia, nawet w późniejszych okresach życia. Model socjalizacji politycznej P.C. Wasburn, T.J. Adkins Covert, integrujący dotychczasowe podejścia analityczne, wydaje się adekwatnym punktem wyjścia w poszukiwaniu równowagi między kontynuacją a zmianą orientacji politycznych oraz definicji ról (np. roli dobrego obywatela w systemie demokratycznym). Pozycjonuje się w nim socjalizację polityczną (głównie z perspektywy jednostkowej) jako wielowymiarowy, dynamiczny i całożyciowy proces "stawania się obywatelem" w określonym kontekście historyczno-społecznym:

Orientacje polityczne osoby dorosłej, umiejscowionej w pewnej strukturze klasowej, wiekowej, płci, rasy bądź etniczności, znajdującej się na określonym poziomie dojrzałości psycho-społecznej, nie są wyłącznie odbiciem teraźniejszej ekspozycji i przetwarzania politycznie znaczących wiadomości, pochodzących z rodziny, kościoła, szkoły, organizacji pracowniczych, dobrowolnych stowarzyszeń czy mediów. Są one po części odbiciem trwałych orientacji nabytych w dzieciństwie, jak precyzuje to zasada pierwszeństwa (the primary principle), a także orientacji nabytych w okresie adolescencji i wczesnej dorosłości, jak precyzuje to zasada lat podatności na wpływy (the impressionable years principle) i zasada strukturyzacji (structuring principle) ${ }^{90}$.

Interdyscyplinarny charakter studiów nad socjalizacją polityczną powoduje, że stosuje się w nich zróżnicowane koncepcje teoretyczne i - mimo sześćdziesięciu bez mała lat badań - niewiele hipotez socjalizacji politycznej doczekało się jednoznacznej i przekonującej weryfikacji bądź falsyfikacji. Interdyscyplinarność może stanowić źródło nie tylko siły, ale także istotnych ograniczeń. Niektóre z powszechnie akceptowanych tez, na przykład - przyjmowane często bezkrytycznie - przekonanie o decydującym wpływie rodzinnej socjalizacji pierwotnej na orientacje polityczne młodzieży, zostały

\footnotetext{
88 Tamże, s. 20.

89 Tamże, s. 40.

${ }^{90}$ P.C. Wasburn, T.J. Adkins Covert, Making Citizens, s. 17.
} 
zakwestionowane. Coraz baczniej zaczęto przyglądać się wpływowi innych instancji socjalizacyjnych, podważając tym samym wcześniej bezdyskusyjną tezę o największej trwałości wartości, postaw i preferencji politycznych, nabytych we wczesnym dzieciństwie. Na późniejszych etapach ludzkiego rozwoju wyolbrzymia się często wpływ procesów starzenia się na zmianę orientacji politycznych osób starszych, nie doceniając znaczenia doświadczeń pokoleniowych oraz przekształceń środowiska i kontekstu społeczno-historycznego dla transformacji orientacji politycznych w okresie dorosłości. Konsekwencją może być nadmierne akcentowanie znaczenia socjalizacji politycznej jako procesu mającego $\mathrm{w}$ perspektywie wyłącznie międzygeneracyjną kontynuację. Umyka wówczas, iż nieuniknionymi i nieodłącznymi wymiarami życia politycznego, pojmowanego zarówno z perspektywy tożsamości jednostkowych, jak i zbiorowych, jest napięcie między kontynuacją a zmianą. Tradycyjne koncepcje (dotyczące np. wzorów obywatelstwa w państwie narodowym) rzadko są w stanie przetrwać bez adaptacji do zmieniających się ewolucyjnie bądź rewolucyjnie warunków środowiskowych. Dla zrozumienia sił kontynuacji i zmiany w procesie socjalizacji politycznej konieczna wydaje się świadomość, że - równoważący tendencje stabilizacyjne - konflikt, choć rzadko prowadzi do radykalnej zmiany, niesie ze sobą modyfikacje, nieodzowne zarówno dla utrzymania integralności jednostkowej oraz pokoleniowej, jak i przetrwania istniejącego systemu politycznego.

\section{BIBLIOGRAFIA}

Adelson J., Beall L., Adolescent perspectives on law and government, Law and Society Review, 1969, 495.

Almond G.A., Introduction: A Functional Approach to Comparative Politics, [w:] The Politics of the Developing Areas, red. G.A. Almond, J.S. Coleman, Princeton University Press, Princeton 1960.

Almond G.A., Komunizm a teoria kultury politycznej, [w:] Wtadza i polityka. Wybór tesktów ze wspótczesnej politologii zachodniej, red. M. Ankwicz, Społeczny Komitet Nauki, Warszawa 1988.

Almond G.A., Powell G.B., Comparative Politics. A Developmental Approach, Little Brown \& Company, Boston 1966.

Almond G.A., Powell G.B., System polityczny, jego otoczenie, wejścia i wyjścia, [w:] Władza i polityka. Wybór tesktów ze wspótczesnej politologii zachodniej, red. M. Ankwicz, Społeczny Komitet Nauki, Warszawa 1988.

Alwin D.F., Krosnick J.A., Aging, Cohorts, and the Stability of Sociopolitical Orientations over the Life Span, The American Journal of Sociology, 1991, 97.

Baltes P.B., Life-span developmental psychology: Some converging observations on history and theory, [w:] Life-span development and behavior, red. P.B. Bates, O.G. Brim, Academic Press, New York 1979. 
Bavir M., Rhodes R.A.W., Teoria interpretacjonistyczna, [w:] Teorie i metody w naukach politycznych, red. D. Marsh, G. Stoker, Wydawnictwo Uniwersytetu Jagiellońskiego, Kraków 2006.

Bokszańska G., Znaczenie kultury politycznej dla funkcjonowania systemu politycznego, Edukacja Polityczna, 1986, 8.

Braungart M.M., Aging and Politics, Journal of Political and Military Sociology, 1984, 12.

Buckingham D., The Making of Citizens: Young People, News and Politics, Routledge, London - New York 2000.

Campbell D.E., Why We Vote: How Schools and Communities Shape Our Civic Life, Princeton University Press, Princeton 2006.

Dawson R.E., Prewitt K., Political Socialization, Little Brown, Boston 1969.

Easton D., Dennis J., Children in the Political System: Origins of Political Legitimacy, McGraw Hill, New York 1969.

Garlicki J., Noga-Bogumilski A., Kultura polityczna w społeczeństwie demokratycznym, Instytut Nauk Politycznych UW, Warszawa 2004.

Geertz C., The Interpretation of Culture. Selected Essays, Basic Books, New York 1973.

Greenberg E.S., Consensus and Dissent: Trends in Political Socialization Research, [w:] Political Socialization, red. E.S. Greenberg, Routledge, London - New York 2017.

Greenstein F.I., Children and politics, Yale University Press, New Haven 1965.

Habermas J., Stichworte zu einer Theorie der Sozialisation, [w:] Kultur und Kritik, red. J. Habermas, Suhrkamp., Frankfurt a. Main 1973.

Hałas E., Refleksyjny podmiot w świecie społecznym. O paradygmacie i założeniach socjologii interpretacyjnej, Roczniki Nauk Społecznych, 2016, 8(44), 4.

Hess R.D., Torney J., The development of political attitudes in children, Aldine Publishing Company, Chicago 1967.

Hyman H.H., Political Socialization. A Study in the Psychology of Political Behavior, The Free Press, New York 1959.

Jacobs L.R., Skocpol T., Health Care Reform and American Politics: What Everyone Needs to Know, Oxford University Press, Oxford 2012.

Jaros D., Socialization in Politics, Praeger, New York 1973.

Jenning K.M., Political Socialization, [w:] The Oxford Handbook of Political Behavior, red. R.J. Dalton, H.-D. Klingemann, Oxford University Press, New York 2007.

Jennings K., Niemi R., Continuity and change in political orientations: A longitudinal study of two generations, The American Political Science Review, 1975, 69.

Jennings M.K., Niemi R.G., Generations and Politics: A Panel Study of Young Adults and Their Parents, Princeton University Press, Princeton - New Jersey 1981.

Johari J.C., Comparative Politics, Sterling Publishers Private Limited, New Delhi 1982.

Lane R.E., Political Maturation in the United States and Germany, [w:] Political Man, red. R.E. Lane, Free Press, New York 1972.

Langton K.P., Political Socialization, Oxford University Press, New York 1969.

Marciniak E.M., Socjalizacja polityczna - wprowadzenie teoretyczne, [w:] Socjalizacja polityczna młodego pokolenia Polaków. Raport z badań kompetencji politycznych, mentalności i postaw politycznych warszawskich licealistów, red. W. Jakubowski, E.M. Marciniak, P. Załęski, Warszawa 2008.

Marvick D., Nixon Ch.R., Recruitment Contrast in Rival Campaign Groups, [w:] Political Decision Makers, red. D. Marvick, Free Press, New York 1961. 
Ostrowski K., Rola związków zawodowych w polskim systemie politycznym, Zakład Narodowy im. Ossolińskich, Wydawnictwo Polskiej Akademii Nauk, Warszawa 1970.

Ross M.H., Culture and Identity in Comparative Political Analysis, [w:] Culture and Politics. A Reader, red. L. Crothers, Ch. Lackhart, St. Martin's Press, New York 2000.

Sasińska-Klas T., Socjalizacja polityczna. Teorie, badania, ustalenia, Rozprawy Habilitacyjne nr 238, Uniwersytet Jagielloński, Kraków 1992.

Schütze F., Trajektorie cierpienia jako przedmiot badań socjologii interpretatywnej, Studia Socjologiczne, 1997, 1.

Searing D.D., Wright G., Rabinowitz G., The Primacy Principle: Attitude Changes and Political Socialization, British Journal of Political Science, 1976, 6.

Sears D., Political socialization, [w:] Handbook of Political Science, red. F.I. Greenstein, N.W. Polsby, Addison-Wesley Educational Publishers, Massachusetts 1975.

Sherrod L.R., Torney-Purta J., Flanagan C., Research on the Development of Citizenship: A Field Comes of Age, [w:] Handbook of Research on Civic Engagement in Youth, red. L.R. Sherrod, J. Torney-Purta, C.A. Flanagan, John Wiley \& Sons, New Jersey 2010.

Sigel R.S., Hoskin M.B., Perspectives on Adult Political Socialization: Areas of Research, [w:] Handbook of Political Socialization, red. S.A. Renshon, Free Press, New York 1977.

Steckenrider J.S., Cutter N.E., Aging and Political Socialization: The Importance of Roles and Transitions, [w:] Political Learning in Adulthood, red. R.S. Sigel, University of Chicago Press, Chicago 1989.

Straś-Romanowska M., I Kongres Psychologów Life-Span: Między psychologia rozwojowa a psychologia rozwoju, Przegląd Psychologiczny, 2001, 44.

Szczepański J., O indywidualności, Instytut Wydawniczy Związków Zawodowych, Warszawa 1988.

Szczepański W., Europa w myśli politycznej de Gaulle’a. Próba analizy systemowej, Państwowe Wydawnictwo Naukowe, Warszawa 1979.

Tillmann K.-J., Teorie socjalizacji. Społeczność, instytucja, upodmiotowienie, Wydawnictwo Naukowe PWN, Warszawa 1996.

Torney-Purta J., Amadeo J.A., Andolina M.W., A Conceptual Framework and Multimethod Approach for Research on Political Socialization and Civic Engagement, [w:] Handbook of Research on Civic Engagement in Youth, red. L.R. Sherrod, J. Torney-Purta, C.A. Flanagan, John Wiley \& Sons, New Jersey 2010.

Trempała J., Natura rozwoju psychicznego, [w:] Psychologia rozwoju człowieka, red. J. Trempała, Wydawnictwo Naukowe PWN, Warszawa 2011.

Verba S., Lehman Schlozman K., Burns N., Family Ties: Understading the Intergenerational Transmission of Political Participation, [w:] The Social Logic of Politics, red. A.S. Zuckerman, Temple University Press, Philadelphia 2005.

Wasburn P.C., Adkins Covert T.J., Making Citizens. Political Socialization Research and Beyond, Palgrave Macmillan, Cham 2017. 